\title{
Religious education, a matter of understanding? reflections on the final report of the Commission on Religious Education
}

\section{Patricia Hannam \& Gert Biesta}

To cite this article: Patricia Hannam \& Gert Biesta (2019) Religious education, a matter of understanding? reflections on the final report of the Commission on Religious Education, Journal of Beliefs \& Values, 40:1, 55-63, DOI: 10.1080/13617672.2018.1554330

To link to this article: https://doi.org/10.1080/13617672.2018.1554330

曲 Published online: 04 Jan 2019.

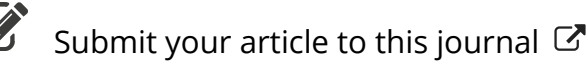

III Article views: 645

Q View related articles $\sqsubset$

View Crossmark data \lceil

Citing articles: 7 View citing articles $\circlearrowright$ 


\title{
Religious education, a matter of understanding? reflections on the final report of the Commission on Religious Education
}

\author{
Patricia Hannam (iD ${ }^{a}$ and Gert Biesta (iD ${ }^{b}$

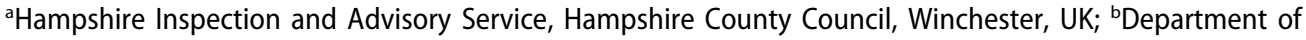 \\ Education, Brunel University London, Uxbridge, UK
}

\begin{abstract}
In this article we offer reflections on the final report of the Commission on Religious Education (CoRE) that was published in England in 2018. We expose and problematise the prominent place of understanding in the report, not only as an educational method, but also the underlying world view of the report itself, a world view which we characterise as 'hermeneuticism'. We raise educational, theological and political concerns about the particular approach taken in the report. We propose instead that religious education (RE) should be considered first of all in terms of what it means to live with a religious or non-religious orientation, conceived in existential terms rather than in terms of beliefs or practices or objectified world views. Educationally we show that what we term a non-hermeneutic way of viewing our humanity would open different possibilities for RE and its future.
\end{abstract}

\section{KEYWORDS}

Commission on Religious Education (CoRE) final report; religious education (RE); hermeneutics; hermeneuticism

\section{Introduction}

The final report from the Commission on Religious Education (CoRE 2018) makes a convincing case for the need for action. The investigations made by the Commission show fairly conclusively that provision of religious education (RE) in England and Wales is patchy, and whilst there are some examples of very good practice around the country, this is frequently also not the case. The report spells out very clearly how the situation for RE has been undermined by a number of government initiatives, including academisation (which particularly has contributed to the erosion of the local infrastructure for RE) and changes to accountability and performance measures (such as the English Baccalaureate (EBacc), which has significantly contributed to the marginalisation of RE in the secondary school curriculum). The report also shows that provision for initial teacher education for $\mathrm{RE}$ in primary schools is non-existent or at best minimal. Against this background, the report makes 11 recommendations which are intended to 'enable all pupils in all schools to receive a high-quality education in Religion and Worldviews' and to 'support and strengthen the subject for the foreseeable future' $(2018,10)$. This is in large part done through the proposal for a 'national entitlement' understood as a 'set of organising principles which form the basis for developing programmes of study' (32). 
In the reflections we offer in this article - first through consideration of the first two main proposals in the report: (1) changing the name of the subject; and (2) making a case for a 'national entitlement' - we begin to expose what seems to be the main assumption underlying these recommendations. In particular, we want to make an intervention that problematises the prominent place of understanding in the report, not just as a method for RE but also, and perhaps first and foremost, as the underlying world view of the report itself. In our view, the emphasis on understanding has come about largely because of the fact that the two constituent dimensions of RE - religion and education - have received insufficient attention in the report. This, as we will conclude, also has problematic implications for the role and position of RE in the public sphere.

\section{From 'Religious Education' to 'Religion and Worldviews'}

The first recommendation of the report is that the name of the subject should be changed from 'Religious Education' to 'Religion and Worldviews' and that this change should be reflected in subsequent legislation and guidance. This is an interesting proposal, particularly because it puts religion in the wider context of world views, and thus potentially offers a broader framing for the subject than an exclusive focus on religion or religious world views would do. One question, however, is what the adoption of the idea of world view entails. In the introduction, a world view is described as 'a person's way of understanding, experiencing and responding to the world', and also as 'a philosophy of life or an approach to life, which includes how a person understands the nature of reality and their own place in the world'. And: 'A person's worldview is likely to influence and be influenced by their beliefs, values, behaviours, experiences, identities and commitments' (4). The report does acknowledge that the notion of world view is not perfect (31), but nonetheless is workable: 'the best fit ... the best available catch-all term to describe both religious and non-religious approaches to life' (31).

In our view the choice for the idea of 'world view' clearly reveals the 'frame' of the report itself - a 'frame' we suggest referring to as 'hermeneuticism'. 'Hermeneuticism' stands for the idea that: (1) the human being is fundamentally a sense-making and meaning-making being; (2) that his or her being in the world is mainly or first and foremost a matter of sense- or meaning-making; and (3) that religious and nonreligious world views play a key role in such sense-making. Although there is some acknowledgement that world views are about more than beliefs - reference is made to practices (see, for example, item 4 of the entitlement; 12), which means that world views are not entirely seen as cognitive belief-systems - it is also very clear that world views are basically understood as 'frames' for sense making. For example, in item 6 of the entitlement, we read:

[Pupils must be taught] how worldviews may offer responses to fundamental questions of meaning and purpose raised by human experience, and the different roles that worldviews play in providing people with ways of making sense of their lives. (12; emphasis added)

If this is, in a sense, a meta-perspective for education - the suggestion here is that pupils must be taught how world views 'work" - there is also a much bolder claim in the report with regard to this, namely that it is one of the core tasks of education to enable 
each pupil to understand, reflect on and develop their own personal worldview' (5; emphasis added). Although it may sound attractive to think of education as the place where each pupil can develop their own personal world view, this suggestion - which is very common in contemporary education discourse - is actually rather problematic. This is because it fails to understand that the real task of education is never just to let everything emerge, but that the more important and more difficult task is to help children and young people to gain a perspective on the personal world view they may want to develop. Key here is the question whether the world view children may want to develop and make their own is going to help them with living well, individually and collectively, or whether the favoured world view will hinder this, in the short or longer term. Education, to put it briefly, is therefore never about mere flourishing - letting a hundred flowers bloom, developing the child's 'full potential' or 'all their talents' - but also has a 'duty to resist' (Meirieu 2007; Biesta 2015), at least in order to bring children and young people 'into conversation' with the world view they desire. ${ }^{3}$

\section{A national entitlement}

The second key recommendation in the report is that of a national entitlement. In our view this is an interesting way to address the key issues RE is currently facing, particularly with regard to the patchy character of provision. At the very same time, the idea of a national entitlement also poses a serious challenge for the field, because it is one thing to argue that everyone should be entitled to good RE, but still another to ask how provision of good quality can be achieved everywhere and for everyone. With regard to the latter, it is remarkable that the report suggests that a national entitlement is best served by a national effort - to be initiated, coordinated and further developed by a committee of nine people rather than through a strengthening and in some cases re-building of the local infrastructure (including the Standing Advisory Councils on Religious Education [SACRE]).

One obvious question to raise is about the proposed composition of the committee of nine where, in the current proposals, academic input is relatively marginal. Our point here is not that of creating particular roles or positions but is linked to a wider concern about the report, namely the absence of any explicit engagement with literature, scholarship and research. This makes it first of all very difficult to see what the proposals are actually based upon. More importantly, it makes it difficult to see what choices were made, what options were considered but rejected, and what the justification, intellectual or otherwise, for all this may have been. This is particularly worrying in light of the report's emphasis on the need for promoting the value of scholarship (see for example 13) because, at least in its presentation, the report does not live up to this need. Rather than assuming that the report provides a sufficiently developed blue-print for the subject and the field and can therefore go straight into implementation \& action' mode, we think that further work on the underpinning and justification of what is being proposed is needed, perhaps rather urgently.

\section{Educational concerns}

Although there is no particular exploration in the report of what it is that education as a whole should seek to achieve, sections 3 and 4 and of Appendix 2 seem to be 
where the underlying educational assumptions of the report start to become more visible, leading us once more to identify what we have termed the 'hermeneuticism' of the report. While a more detailed discussion of hermeneuticism will have to come later, there are two concerns that we want to raise in the context of our reflections. The first is educational; the second is 'at least' existential, which means that it is political, theological, and in a sense educational as well. The issues are particularly visible in Appendix 2, perhaps epitomised in the following to two claims: (1) That 'the subject matter of RE as worldviews' is about '( $\mathrm{t}$ )he individual process of making sense of life and making meaning of experience' (72); and (2) That central to the 'aims, purposes and nature of Religion and Worldviews' is 'understanding the human quest for meaning' (73).

With regard to the educational point, it is important to see that the report not only has a hermeneutic understanding of human beings and their ways of existing in the world, but also thinks of education itself predominantly as a hermeneutic exercise, that is an exercise that functions as and should result in understanding, particularly understanding of what world views are, how they operate, and which world views there are. When, in the description of the entitlement, we read that 'teaching must promote openness, respect for others, objectivity, scholarly accuracy and critical enquiry' (13), the question immediately emerges how teaching should do this, also bearing in mind that these ambitions are rather huge. The main answer provided in the report seems to be: through working on (better) understanding. On page 26 , for example, the report says that '(y)oung people need both to understand the worldviews of others and reflect on their own' and on page 27 it says that 'understanding worldviews enables young people to understand a wide range of human experience'. There are also quotes from young people that seem to indicate that because they have enhanced understanding, they have become able to establish respectful friendships 'across difference', but such quotes are rather selective and mainly seem to provide illustration.

One could of course say that it is wonderful when this happens, that is, when enhanced understanding does lead to a change in attitude, but the claim that understanding is the key 'mechanism' here, cannot be substantiated. Understanding does not automatically translate into emphatic action, if that phrase is useful here, a point brought home pretty well when Homer Simpson, in an episode of The Simpsons, said to his children: 'just because I don't care, doesn't mean I don't understand' (for a detailed discussion see Biesta 2017a). The point here is, that understanding does not automatically translate into care, or respect, or friendship, and educationally it might therefore actually be better to radically disconnect the two. This would amount to saying that understanding is a laudable aim for education. Indeed, promoting care and respect may also be a laudable aim, but our point is that there is no automatic connection from the one to the other. This is also because enhanced understanding can lead to the opposite: to disrespect, hate, and so on. Terrorists, to make the point one more time, tend to have a very good understanding of other people's world views; that is to say they have made their own meaning from such world views. The problem lies in the consequences they draw from such understanding, that is, what motivates their actions and prompts them to act. This is where educational hermeneuticism runs into problems, and the report seems to be largely unaware of this, which seems to indicate that education may turn out to be one of the 'forgotten dimensions' in the report. ${ }^{4}$ 


\section{Existential concerns (1): theology}

The other problem we see with regard to the hermeneuticism of the report is existential, having to do with the fact that the report relies on a very particular an unquestioned view of the human being and its place in and relation with the world. This, as we have already mentioned, is the idea of the human being as a sense- and meaning-making being for whom the world, social and natural, appears as an object of sense- and meaning-making. One question is whether or not such a view of the human being 'makes sense'. Another question is whether such a view is inevitable, that is, whether it is the only way to articulate the place of the human being in the world. With regard to the latter question, we can at least point to the work of philosophers such as Heidegger, Sartre and Levinas, who all have tried to articulate rather different accounts of the way in which human beings are in the world - thrown into the world, with a duty to care for the world, condemned to be free, addressed by the world, and so on. ${ }^{5}$ What the implications of such accounts are, lies beyond the scope of these reflections, but the existence of non-, a- or even anti-hermeneutic accounts of the human being at least indicates that the hermeneuticism informing the report is a particular choice that, therefore, needs justification.

These questions are not just philosophical. There is also a theological corollary to the point we are making here, because an idea that seems to be completely absent in the conception of the human being presented in the report is that of revelation, that is, that rather than that human beings 'make sense' and 'give meaning', something is actually given to them that radically breaks through such meaning-making. 'Decentred' conceptions of the human being are, to put it differently, not the prerogative of twentiethcentury philosophy, but are also key to religious and theological traditions. Perhaps this is the most important reason why we wish to suggest that a proposal for the future of RE cannot, without further discussion, rely on an anthropocentric or 'immanent' world view. ${ }^{6}$ The fact that this discussion is absent in the report may indicate that religion appears as the other 'forgotten dimension' in the discussion (Hannam and Biesta 2019).

\section{Existential concerns (2): politics}

A further consequence of the approach taken in the report is the risk that the child or young person is mainly positioned as an 'understander' or interpreter of things others put before them - which would become even more of an issue if assessment and examination would focus predominantly on how well pupils have 'performed' in the task of understanding. This puts pressure on the possibility of what, after Hannah Arendt, we could term their 'natality', that is, their capacity to begin and to bring their beginnings into the world. This is not a matter of selfexpression and even less so of choice - hence our concerns about the idea that education should merely be about children developing their 'own' world view but is fundamentally political in that, again following Arendt, the only way in which our beginnings can come into the world, is in their 'meeting' of the beginnings of others, which will necessarily transform, disrupt and in some cases even destroy our beginnings. 
Yet this is precisely the 'human condition' (Arendt 1958), that is, the way in which human beings can 'appear' in the world, with others, rather than remain entirely private and for themselves. Where education is considered as being the kind of activity primarily concerned with bringing the child to understand, the possibility of action, of taking initiative and letting such initiative 'go' into the world of plurality and difference, will be significantly curtailed. If education and, more specifically, RE has a concern for the public sphere, for the life we live together with others, it needs to make sure that children and young people can begin and, most crucially, encounter the beginnings of others in this process. ${ }^{7}$

The loss of such an understanding of what political life, life in the polis, life in the presence of others, can be seen in a very practical way in recommendation 8 . This is where the report proposes the establishment of Local Advisory Networks for Religion and Worldviews (LANRW) to replace the existing SACRE. The disengagement of these new bodies from the democratic processes in England, illustrates starkly the way in which the proposals in this report seem to move aside from the public sphere, placing it instead in the context of the contemporary educational market place. What is distinctive about the existing SACREs is the presence of locally elected members of government, which ties them fundamentally into democratic accountability. Shifting the new body into a context where there is no clear accountability, save to itself, runs the danger of placing RE outside of the public sphere, so that it becomes less able to make its unique contribution there.

\section{And what about teachers and their teaching?}

A final set of problems we would like to identify, relates to the teacher and what she is to do and to seek to achieve, as a consequence of her teaching. Section 6 (45-51), entitled 'Developing High Quality Teaching', cites two reports, one carried out by National Association of Teachers of Religious Education (NATRE) and another by the Organisation for Economic Cooperation and Development (OECD). Both are intended to justify the report's emphasis on subject knowledge, assuming that if only the teacher had enough specialist knowledge, standards in RE would improve. However, this idea, taken together with educational assumptions and positioning the child as a 'meaning-maker' or 'understander', reduces the teacher to the role of 'facilitator' or 'enabler' of children's making of meaning and understanding and thus dissolves the unique 'work' of teaching and the teacher in the educational process (see Biesta and Hannam 2016).

There are also theological and political consequences present for the teacher in the report. Theologically, the approach taken in the report limits the way in which religion (and world views) are conceptualised; restricted to the kinds of things that are believed or practiced and therefore capable of being studied objectively in some way. This risks relegating the teacher to a kind of technician, who needs to find the right 'methods' to deliver a curriculum that apparently can 'promote openness, respect for others, objectivity, scholarly accuracy and critical enquiry' (35). What it means to live a life with a world view is objectified as something to be studied; any question as to the significance of living a life with a religious orientation in existential terms is missing from the report. This will have political consequences too, since the power of what it is to live 
a human life with a religious or other orientation runs the risk of disappearing from the educational conversation.

Where the existential dimension is included, the role of the teacher becomes that of bringing the child to attend, not to any particular thing necessarily but to a different position in relation to the world (see Biesta and Hannam 2016; Hannam 2019 for more extended discussions of this). In understanding her role as bringing the child to 'attention, intellectual humility and discernment' (Weil 1965) the teacher has scope for bringing all ways in which it is possible to live a life into the classroom. There will be intellectual engagement but also discernment regarding how to live life, as the child's beginnings meet those of others. The teacher has a responsibility here in all the many ways she lives and moves with children in the school. Clearly the possibilities from this are less than certain (Hannam 2018), however in Arendtian terms, this is how action is possible and where the public sphere can exist.

\section{Conclusion}

There is much to commend the report for in terms of its intentions to remedy increasingly patchy provision of RE across the country as well as identifying what has brought this about, namely academisation and changes to the accountability measures. However, in this article we have sought to identify what we see as the main shortcomings of the report and have argued that these should be addressed as a matter of urgency before the whole endeavour goes into implementation mode. Our concerns flow from what we have termed the 'hermeneuticism' of the report. We have sought to show how, if left unattended, particular assumptions regarding educational purpose will become dominant. These are assumptions that will limit what teachers can achieve and how they are to do that, regardless of what the subject is called. We have also identified a shortcoming regarding the theological positioning of religion and world views. Here religion is predominantly conceptualised as belief and practice, which runs the risk of objectifying religion and reducing the teacher to a facilitator or technician. Finally, we have sought to reveal the political implications of the assumptions upon which this report is resting. The likely consequence of moving too quickly into implementation mode, especially if this is handed over to commercial organisations without the measured guidance of serious scholarship, will be the loss of the public sphere. Arendt has warned of the dangers of replacing the public sphere, which is the space of appearance, with economics (see for example, Arendt 1951). We commend this warning loud and clear to the Religious Education Council as they seek to act on the recommendations of the report.

We would propose what we might term a non-hermeneutical alternative. This would be one which approaches both education and religion from a different angle (see for example Biesta 2017c; Hannam 2019; Biesta \& Hannam 2019). In this alternative proposal, educational questions would be considered first and foremost and questions about what it means to live with a religious or non-religious orientation considered in existential terms and not only as beliefs or practices or objectified world views. Educationally we would want to show that a non-hermeneutic way of viewing our humanity would open different possibilities for what the teacher should seek to achieve in her relationships with children and young people in school. Further, were these 
dimensions considered first, were bringing the child to speak and act in a world of others taken as the organising principle of an RE curriculum, things might look rather different.

\section{Notes}

1. We use the rather awkward term 'hermeneuticism' to distinguish it from hermeneutics. Our concern here is not with the role that understanding may or may not play in education - albeit that we have questions about that as well - but first of all with the underlying view of human beings, their place in and their relationships with the world. For a more detailed analysis and critique of 'hermeneuticism' in contemporary education see, for example, Biesta (2016).

2. An interesting 'case' for such an approach can be found in Enoch (2004), who builds on the work of Kenneth Burke; see also Rutten and Soetaert (2012) and, for a critical discussion, Biesta (2012).

3. Elsewhere in the report there is an awareness of this predicament, when it is stated that 'some types of extremism ... draw on particular religious and non-religious worldviews' (28). But to suggest that those with extremist world views don't understand what a world view is - see page 28 , section 28 - is rather naïve, as one could also argue that those holding extremist world views, know rather well what a world view is, and what it is capable of.

4. On the idea that education and religion are forgotten dimensions of religious education see Hannam and Biesta (2019).

5. At this point we only refer to a number of significant alternatives within contemporary Western philosophy. There are, of course, also non-Western and older, pre-modern, accounts of the human being that differ significantly from hermeneuticism.

6. For a discussion of the educational implications of immanence and transcendence see Biesta (2017b).

7. For a detailed discussion of these dynamics and an argument for the need for education to be in, with and for the public sphere and public existence, see Hannam (2019).

\section{Disclosure statement}

No potential conflict of interest was reported by the authors.

\section{Notes on contributors}

Gert Biesta is Professor of Education in the Department of Education at Brunel University London, UK, and NIVOZ Professor for Education at the University of Humanistic Studies, the Netherlands. In addition, he is visiting professor at NLA University College, Bergen, Norway, and the University of Agder, Norway. His work focuses on the theory of education, education policy, and the theory and philosophy of educational and social research. His most recent book, The Rediscovery of Teaching, was published with Routledge in 2017.

Patricia Hannam (PhD Stirling University) is County Inspector Adviser for Religious Education, History and Philosophy, leading and advising on teaching and curriculum development in religious education and history. She has particular interest in the ideas of Arendt and Weil, and how schools and other educational contexts can be places where the thinking, speaking and action necessary for all to flourish, can happen. Her book Religious Education and the Public Sphere published with Routledge in 2018. 


\section{ORCID}

Patricia Hannam (D) http://orcid.org/0000-0002-8810-3252

Gert Biesta (D) http://orcid.org/0000-0001-8530-7105

\section{References}

Arendt, H. 1951. The Origins of Totalitarianism. Orlando: Harcourt, .

Arendt, H. 1958. The Human Condition. Chicago, IL: University of Chicago Press.

Biesta, G., and P. Hannam. 2016. "Religious Education and the Return of the Teacher." Religious Education 111 (3): 239-243. doi:10.1080/00344087.2016.1172854.

Biesta, G. J. J. 2012. "Becoming World-Wise: An Educational Perspective on the Rhetorical Curriculum.” Journal of Curriculum Studies 44 (6): 815-826. doi:10.1080/00220272.2012.730285.

Biesta, G. J. J. 2015. “The Duty to Resist: Redefining the Basics for Today's Schools.” Research on Steiner Education 6/Special Issue 2015 1-11.

Biesta, G. J. J. 2016. “The Rediscovery of Teaching: On Robot Vacuum Cleaners, Non-Egological Education, and the Limits of the Hermeneutical World-View." Educational Philosophy and Theory 48 (4): 374-392. doi:10.1080/00131857.2015.1041442.

Biesta, G. J. J. 2017a. Letting Art Teach: Art Education after Joseph Beuys. Arnhem: ArtEZ Press.

Biesta, G. J. J. 2017b. "P4C after Auschwitz: On Immanence and Transcendence in Education." Childhood and Philosophy 30 (28): 617-628.

Biesta, G. J. J. 2017c. The Rediscovery of Teaching. London, NY: Routledge.

Commission on RE 2018 Final Report

Enoch, J. 2004. "Becoming Symbol-Wise: Kenneth Burke's Pedagogy of Critical Reflection." College Composition and Communication 56 (2): 272-296. doi:10.2307/4140650.

Hannam, P. 2018. “Religión en la educación: ¿problema, paradoja o posibilidad?” Acontecimiento 125: 55-59.

Hannam, P., and G. Biesta, Eds. 2019. Education and Religion: The Forgotten Dimensions of Religious Education?

Hannam, P. 2019. Religious Education and the Public Sphere. London: Routledge.

Meirieu, P. 2007. Pédagogie: Le devoir de résister. Issy-les-Moulineaux: ESF éditeur.

Rutten, K., and R. Soetaert. 2012. "Revisiting the Rhetorical Curriculum." Journal of Curriculum Studies 44 (6): 727-743. doi:10.1080/00220272.2012.730280.

Weil, S. 1965. Waiting on God. London: Fontana Books. 